\title{
Kuşaklar Bağlamında Tüketici Sağlığı Bilişimine Yönelik Bir Araştırma ${ }^{1}$
}

\section{A Research on Consumer Health Informatics in the Context of Generations}

\section{Hilal Demirhan ${ }^{2}$ - Dr. Öğr. Üyesi Erdal Eke}

Başvuru Tarihi: 16.08.2019

Kabul Tarihi: 25.09.2019

Öz

Bu araştırmanın amacı, kuşakların sağlık hizmetlerinde tüketici sağlığı bilişimi teknolojilerine yönelik kullanım düzeylerini tespit etmektir. Bu kapsamda Isparta'da yaşayan 431 bireyden toplanan veriler değerlendirilmiştir. Yapılan analizler; tüketici sağlı̆̆ı bilişimi kullanımının kuşaklar arası değişkenlik gösterdiğini ve kullanım düzeylerinin $Y>X>Z$ şeklinde sıralandiğı sonucunu ortaya koymaktadır.

Anahtar Kelimeler: Sağlık Hizmetleri, Sağllk Teknolojisi, Kuşak, Tüketici Sağlı̆ğ Bilişimi, Sağlık Yönetimi

\section{Abstract}

The aim of this study is to determine the usage levels of generations for consumer health informatics technologies in health services. In this context, data collected from 431 individuals living in Isparta were evaluated. Analyzes; It shows that consumer health informatics use varies between generations and the usage levels are listed as $Y>X>Z$.

Keywords: Health Services, Health Technology, Generation, Consumer Health Informatics, Healthcare Management

\footnotetext{
${ }^{1}$ Bu çalıșma “X, Y ve Z Kușakları Açısından Tüketici Sağlığı Bilișimine Yönelik Bir Alan Çalıșması” bașlıklı yüksek lisans tezinden uyarlanmıștır.

${ }^{2}$ Süleyman Demirel Üniversitesi Sosyal Bilimler Enstitüsü Doktora Öğrencisi, hilalhan@e-mail.com.tr, ORCID: 0000-0001-5602-5029

${ }^{3}$ Süleyman Demirel Üniversitesi İktisadi İdari Bilimler Fakültesi, erdaleke03@gmail.com, ORCID: 0000-0001-5602-5029
} 


\section{Giriş}

Sağlık teknolojisi, teknoloji ile bütünleşik ilerleyen, bireyin sağlık sorunlarına çözüm bulmada ve yaşam standartlarını arttırmada çeşitli cihaz, ilaç prosedür ve sistemlerin geliştirilmesi şeklinde ifade edilmektedir (World Health Organization, 2019). Teknolojideki hızlı değişim aynı zamanda sağlık teknolojilerindeki hizmet şeklinin de değişmesine neden olmakta bu durum sürekli bir döngü halinde devam etmektedir.

Sağlık teknolojisine yönelik sağlık hizmetleri, bilinç düzeyinin artması, istek ve önerilerdeki değişimler, bu alanda gelişmiş ülkelerin etkisi ve hizmetin etkin, güvenilir, kaliteli ve ülke bütçesine katkı sağlaması gibi etmenler sağlık teknolojisine yönelik hizmetleri çeşitlendirmiştir. Literatüre bakıldığında sağlık teknolojisi hizmetlerinin dağınık bir şekilde incelendiği gözlemlenmiştir. Buradan hareketle sağlık teknolojileri kapsamında verilen hizmetlerin sınıflandırma gereği duyulmuştur. Bu nedenle çalışmada sağlık teknolojileri hastanede bir sağlık çalışanı tarafından verilen "Hastane Bazlı Sağlık Teknolojileri” ve bireyin hizmet almada kendisinin rol oynadı̆̆ı “Tüketici Sağlı̆̆ı Bilişimi” olmak üzere iki başlıkta incelenmiştir. Çalışmada ağırlıklı olarak tüketici sağlığı bilişimi kapsamında verilen sağlık hizmetlerinden bahsedilmiştir.

Sağlık teknolojisine yönelik hizmetler başlarda hastane odaklı yani daha çok sağlık kuruluşlarında bir sağlık çalışanı yardımı ile verilen hizmetler olarak nitelendirilmektedir. $\mathrm{Bu}$ teknolojilerden bazıları; bilgisayarlı tomografi, manyetik rezonans gibi tıbbi cihazların tamamı, tansiyon aleti, enjektör gibi tıbbi malzemelerin tamamı ve diğer teknoloji odaklı hizmetler şeklindedir (Türk Tabipleri Birliği, 1999, s. 11). Diğer yandan tıpta yaşanan gelişmeler öncelikle hekimler ve diğer sağlık çalışanları için geliştirilen bu teknolojik sistemler son birkaç on yılda bilgisayar ve telekomünikasyon sistemleri ile tüketicilere ve hastalara kaymıştır. "Tüketici Sağhlğı Bilişimi” olarak adlandırılan bu alanda tüketicilerin bilgiye ulaşmasını sağlamak için yöntemler araştırılır ve uygulanır. Aynı zamanda tüketicinin isteğine göre bilgi sistemleri modellenir ve entegre edilir (Eysenbach, 2000, s. 1713).

İnsanların bilgi edinme isteği, artan farkındalık düzeyi ve özellikle kendisi söz konusu olduğunda hassas yaklaşımları tüketici sağlığı bilişimi gelişmelerini hızlandırmıştır. Bu noktada hastaların internet üzerinden tıbbi kayıtlarına erişmesi, sağlık çalışanlarının da tıbbi verilere ulaşması ile hekimle iletişim kurulması ek olarak herhangi bir sınırlandırma olmadan hastahekim ilişkisinin hastane dışına taşınması ve böylelikle uluslararası alanda bile hizmet alımının kolaylaşması (Cheong vd. 2009: s. 267) tüketici sağlı̆̆ı bilişimini katkılarına örnek gösterilmektedir. Tüketici sağlığı bilişiminin amaçları değerlendirildiğinde alanın verdiği hizmetin internet ve bilişim teknolojilerin tabanında sağlık hizmetlerinin verilmesini kolaylaştıran bir elektronik sağlık platformu olan e-Sağlık teknolojileri ile gerçekleştirildiği görülmektedir.

Çalışmada, tüketici sağlığı bilişimi, güncel sağlık teknolojileri ve bu teknolojilerin tabanında yer alan yapay zeka, yapay zekanın sağlık hizmetlerindeki gelişmeleri ve kuşak sınıflandırmalarından bahsedilmiştir. Son olarak Isparta il merkezinde yaşayan 18-54 yaş arası 
bireylerin demografik ve birtakım değişkenler çerçevesinde tüketici sağllğı bilişimi kullanımlarını değerlendirmek üzere "Tüketici Sağlığı Bilişimi Teknolojilerinin Değerlendirilmesi Anketi” uygulanmıştır. Ayrıca araştırmanın amaç, yöntem, kısıtllılıları ile analiz tabloları ve boyut karşılaştırmalarına yer verilmiştir. Analizler SPSS 22.0 paket programında yapilmıştır.

\section{Kavramsal Çerçeve}

Tüketici sağlığı bilişimi ismi ilk olarak 1993 yılında Tom Ferguson ve meslektaşları tarafından ABD'de düzenlenen, "Tüketici Sağhlğı Bilişimi: Hastayı Loop'a Getirmek” başlıklı bir konferansta geçmiştir. Aynı yılın ilerleyen zamanlarında Warner Slack ve Tom Ferguson, Washington DC'deki Amerikan Tıp Bilişim Derneği Yıllık Toplantısında aynı başlıkta yarım günlük bir eğitim vermiştir. Hem Wisconsin konferansı hem de eğitim için kullanılan Amerikan Tıp Bilişim Derneği Dergisi (Journal of the American Medical Informatics Association-AMIA) el kitabı yeni bir öngörü içermektedir. "Yeni nesil tıbbi bilgi işlem sistemi, sadece hekime değil, hastaya da hizmet verecek" bu yeni sistem, sağllk hizmetini yeniden icat etme, hastaları sağlayıcılara dönüştürme ve bir düğmeye dokunarak özelleştirilmişs sağlk hizmetleri verme amaçlarını gütmektedir (Ferguson, 1993).

Bir tanım olarak tüketici sağlı̆̆ı bilişimi, sağlık hizmetleri uzmanı olmadan tüketiciye kişiselleştirilmiş yardım sağlayan, tüketicilerle doğrudan etkileşimde bulunmak için tasarlanan teknoloji, elektronik cihaz veya elektronik uygulamalardır. Bu teknoloji ile tüketicilerin kendi sağlık hizmetlerinde daha aktif rol almalarını ve karar vermelerini sağlamak amaçlanmıştır (Jimison ve Sher, 1995, s. 783; Gibbons vd. 2011, s. 73). Bireylerin sağllk bilgilerine erişmesinin yanında bu bilgileri kullanmalarını sağlayan, elektronik araçlar ve uygulamalar rahatsızlıkları boyunca sürece katılmalarını teşvik etmektedir. Sonuçta tüketici sağlığı bilişimi ile bireylerin kendi sağlıkları için sağlık profesyonelleri ile etkileşimleri sağlanmış günümüzde hasta katılımı ve hastanın güçlenmesi önemli hale gelmiştir (Anderson vd. 2012, s. 2).

Sağlık hizmetlerinde teknoloji ve bilişimin bütünleşmesi sağlık hizmetlerinin elektronik ortamla verilmesi, tüm verilerin saklanması ve teşhis, tedavi ve sonuçların değerlendirilmesinde web tabanlı sistemlerin kullanılması, sağlığın teknoloji çağındaki ismi e-Sağlık ile adlandırılmaktadır (Toygar, 2018, s. 101). e-Sağlık, günlük koşullara uygulanan hizmetleri ile (hasta bakımı, koruyucu hekimlik, sağlık teşviki, toplum düzeyinde sağlık iletişim kampanyaları ve sağlık profesyonellerine yardımcı olmak) tüketici sağlı̆̆ bilişimi kapsamında değerlendirmektir. Temel beceriler göz önünde bulundurularak e-Sağlık sistemi tüketici sağllğı bilişimi kapsamında değerlendirmek kaçınılmazdır (Norman ve Skinner, 2006, s. 8).

DSÖ'ye göre e-Sağlık, 2000 yllında ortaya çıkan gelişmeleri destekleme, uzak bölgelerde yaşayan kesime hizmet verme, sağlık işgücünün ve eğitiminin öğrenimi, doğru zamanda doğru tanı ve tedavi ile hastayı iyileştirme amaçlarında bilişim teknolojilerinin sistemli kullanılması şeklinde tanımlanmaktadır (World Health Organization, 2016a, s. 8; Pagliari vd. 2005, s. 3). e-Sağllk sadece kendi başına bir sistem olmaktan öte pek çok alt bileşeni de içinde barındırmaktadır. Bunlar; 
- Mobil Sağhlk (m-Săglık): Akıllı telefonlar ve diğer teknolojik cihazlar ile sağlık hizmetlerinin ve sağlık bilgilerinin verilmesine yardımcı olan bir sağlık teknolojisidir (World Health Organization, 2009, s. 8; World Health Organization, 2011, s. 6). MHRS (Merkezi Hekim Randevu Sistemi), e-Nabız, İlaç Takip Sistemi, 112 acil yardım butonu, Diş Fırçalama uygulaması ve ESİM (Engelsiz Sağlık İletişim Merkezi) Sağlık Bakanlığı tarafından geliştirilen mobil sağlık uygulamalarıdır (Sağlık Bakanlığı, 2016).

- TeleTıp: Uzak mesafeler arasında sağlık bakımını ifade eden bir terimdir. Genel anlamda TeleTıp tıbbi bilgi ve teknolojik hizmetleri sağlayan telekomünikasyon kullanımı olarak da tanımlanmaktadır. TeleTıp'ın ana noktası bilgileri bir yerden diğerine elektronik sensörlerle aktarmasıdır (Zach, 1996, s. 409).

- Elektronik Sağlık Kayıt Sistemi: Kişinin doğumundan ölümüne kadar geçen süre boyunca ruhsal ve fiziksel sağlı̆̆ ile ilgili bilgileri toplayan, ileten en önemlisi de saklayan bir sağlık hizmetidir (Sağlık Bakanlığı, 2014a).

- Internet ve Sosyal Medya Kullanımı: İnsanların bilgi ve birikimlerini, istek ve önerilerini hızlı ve kolay bir şekilde paylaşabileceği aynı zamanda sağlık hizmetlerine erişim için kullanabileceği internet ortamlarıdır.

- Giyilebilir Teknolojiler: Vücuda yapışan ya da giyilebilen teknolojik cihazlardır.

Tüketici sağlığı bilişimindeki gelişmeler insanlardaki bilinç düzeyini arttırmakta ve onları geleceğe yönelik daha fazla beklenti içerisine sokmaktadır. Tam da bu aşamada sağlık teknolojileri yeniliğin ve teknolojinin bir diğer adı olan yapay zekâ alanına yönelmiştir. eSağlıkla şekil bulan tüketici sağlığı bilişimi yapay zeka ile kendini tamamlamak üzere çalışmaları sürdürmektedir.

Diğer bilimlerden farklı olarak insan davranışlarını temel alan yapay zekâ, insanın duygu ve düşünce yapısını bilgisayar sistemlerine aktarma çalışmaları yapan bilim dalı olarak tanımlanmaktadir. Basit bir anlatımla yapay zekâ bilgisayar tabanlı sistemlere bilgi edinme, görme, düşünme ve hüküm verme yetilerini kazandırmak diğer yandan insanın düşünce yapısından yola çıkarak insan özelliklerinin bir emsalini bilgisayar sistemlerine uygulayan bir bilimdir (Keleş, 2007, s. 32-33; Yazıcıoğlu, 2010, s. 15). Yapay zekâ, e-Sağlık için merkez teknoloji konumuna yerleşmiştir. Basit örneklerle mesaj hatırlatıcılar, uyku, egzersiz ve kan şekeri monitörleri ve sağlık koçu niteliğinde çalışan avatar gibi karmaşık algoritmalar tüketici sağlığı bilişimi teknolojileri içerisindedir. Yapay zekâ bir devrim yaratarak e-sağlık platformunda yer almış, insanların sağlığını anlamak ve yönetmek için kişiselleştirilmiş araçlara erişimlerini sağlamıştır (Kreps ve Neuhauser, 2010, s. 334).

Çalışma boyunca geçmiş, bugün ve geleceğe dair tüm teknolojik gelişmeler değerlendirildiğinde bireylerin tüketici sağlığı bilişimine yönelik kullanım ve fayda düzeyleri kuşaklarla ele alınmıştır. Kuşaklar belirlenirken farklı yıl, sosyo-ekonomik, siyasal ve kültürel özelliklere sahip gruplar farklı şekilde adlandırılmaktadır. Literatür kapsamında Sessiz Kuşak (1900-1945), Bebek Patlaması Kuşağı (1946-1964), X Kuşağı (1965-1980), Y Kuşağı (1980-1999) ve Z Kuşağı 
(2000 ve sonrası) şeklinde beş kuşak incelenmiş ancak günümüzde yaygın yaş sınıflandırmasından dolayı X, Y ve Z kuşakları çalışmaya dâhil edilmiştir.

Teknolojik sürecin başladığı 1965’lı yıllar bu dönemde yaşayan X kuşağı, kişisel teknolojik ürünlerin ortaya çıkması ile gelişmelere ayak uydurmaya çalışmış ve günlük hayatında iletişim kurmak için bu ürünleri (telefon, bilgisayar, kişisel e-posta vb.) kullanmıştır. X kuşağının diğer kuşaklara nazaran teknolojiye katkısı fazla olmasına rağmen kullanımı azdır (Büyükuslu, 2017, s. 10). Diğer nesil 1981-1995 yıllarında doğan Y kuşağıdır. Bu kuşak teknoloji ve internetin en yoğun kullanıldığı zamanda doğmuştur. Teknolojiyi hayatlarının her alanında kullandıklarından dolayı istedikleri her bilgiye rahatlıkla ulaşabilen ve her şeyi başarabileceğini düşünen özgür kişilerdir (Büyükuslu, 2017, s. 10-11). Y kuşağının büyük bir kısmı tüketici sağlığı bilişimi kapsamında sağlık portallarına katılma, giyilebilir cihazlarla sağlık durumlarını izleme ve çevrimiçi topluluklara katılma gibi faaliyetlerde bulunmaktadır. Kuşağın belli bir kısmı internet ortamında yapılan sağlık araştırmaları ile kendi kendini tedavi etmiş veya sağlığı için online olarak yardım istemiştir (Lerman, 2014, s. 5-8-36). Z kuşağı 2000 ve sonraki yılları kapsayan teknolojinin çok kullanıldığı dönemde doğmuştur. Günlük yaşamda teknoloji kullanılan her alanda internet ve sosyal medya gibi dijital teknolojilerin ve bilgisayar, cep telefonu gibi elektronik cihazların gelişmesine tanık olmaları bu alanda çokça bilgi sahibi olduklarının göstergesidir (Büyükkeçeci, 2017, s. 10-26; Biztatar, 2017, s. 61). Sağlık hizmetlerinde tüketici sağlı̆̆ bilişimi teknolojileri her ne kadar hayatı kolaylaştırsa da kullanım oranı beklenilen seviyelere ulaşmamıştır. Kulanım düzeyi özellikle kuşaklar arasında incelendiğinde fark net bir şekilde görünmektedir.

\section{Metodoloji}

\section{Araştırmanın Amacı ve Önemi}

Çalışmanın ana amacı, bireyleri ait oldukları kuşaklara göre inceleyip tüketici sağlı̆̆ı bilişimi kullanım düzeylerini ölçmektir. Yapılan incelemeler sonucunda kuşaklar arasında tüketici sağlığı bilişimi kullanımına yönelik farklılık olup olmadığ 1 ortaya konulacaktır. Bu bilgiler doğrultusunda alt amaçlar ise bireylerin tüketici sağlığı bilişimi bilgi ve fayda düzeyleri göz önünde bulundurularak gelecek beklentilerini değerlendirmek ve gelişmiş hizmetlerin sunulması hususunda çalışmaların önünü açmaktır. Çalışma, Türkiye'de sağlık teknolojileri alanında yapılan çalışmaların kısıtlı olması ve sağlık hizmetleri alanında bu konuyla ilgili yeterli çalışmanın mevcut olmaması nedeniyle öncül bir nitelik taşımaktadır. Diğer taraftan çalışmanın tüketici sağlığı bilişimi kullanımının kuşaklar açısından incelenmesi alanda daha ayrıntılı bir bilgiye ulaşılmasına yardımcı olacaktır.

\section{Araştırmanın Kısıtları}

Araştırma, Isparta il merkezinde yaşayan 18-54 yaş aralığındaki yetişkin bireyleri kapsamaktadır. Araştırmanın verileri 2019 yılı Mayıs ayında toplanmış olup sonuçlar evrenin bu zamandaki özelliklerini yansıttığı için genellenememektedir. Araştırmanın, Isparta dışındaki diğer iller veya ülke bazında genellenebilmesi için daha geniş çaplı bir örneklem üzerinde çalışılması gerekmektedir. 


\section{Evren ve Örneklem}

Bireylerin tüketici sağlı̆ğ bilişimi kullanımları değerlendirildiğinde bu çalışmanın evrenini, Isparta il merkezinde yaşayan 18-54 yaş aralığındaki tüm bireyler oluşturmaktadır. Türkiye toplam nüfusu Isparta nüfusuna (258.375) indirgenerek bir hesaplama yapılmıştır. TÜİK verilerine göre 2018 yılı Türkiye nüfusu 81.867.223 kişiden oluşmaktadır. Araştırmada Türkiye genelinde X kuşağı bireylerinin toplam sayısı (15.832.599) göz önünde bulundurularak 90 kişiye, Y kuşağında bireylerinin toplam sayısı (25.662.902) göz önünde bulundurularak 168 kişiye ve Z kuşağında bireylerinin toplam sayısı (25.606.597) göz önünde bulundurularak 173 kişiye ulaşılmıştır.

Bir araştırmada örneklemin ne kadar olması konusunda kesin bir sayı vermenin mümkün olmadığ 1 bilinmektedir. Fakat evrenin belli olduğu durumlarda \%95 güven aralığ $1 \% 5$ hata payı olarak alındığında mevcut evrende ulaşılması gereken örneklem sayısı 384 olarak hesaplanmaktadır (Dişçi, 2008, s. 94). Araştırmada kotalı örnekleme yoluyla 431 anket değerlendirilmeye alınmıştır.

\section{Veri Toplama Aracı}

Araştırmada kullanılan anket formu araştırmacı tarafından geliştirilmiştir. Anketin hazırlanması aşamasında öncelikle ulusal ve uluslararası düzeyde literatür taraması ile anket sorularını hazırlamak için Işıkdemir Uluç (2016), Bal ve diğerleri (2012), TÜİK (2017), Göktaş vd. (2017), WHO (2015), Mendi (2012)'nin çalışmalarından yararlanılmıştır. Anket sorularının geliştirilmesi aşamasında Sağlık Yönetimi Bölümü akademisyeni 1 Profesör, 1 Doktora Öğretim Üyesi ve 2 Araştırma Görevlisinden uzman görüşü alınmıştır. Hazırlanan anket sorularının anlaşılabilirliğini denetlemek amacıyla, kotalı örnekleme yöntemiyle 50 kişilik grup üzerinde pilot çalışma yapılmıştır. Anlaşılmayan ve tekrar eden sorular yeniden düzenlenmiş ve katılımcılara yöneltilen anket meydana getirilmiştir. Veri toplama aracı olarak kullanılan anket üç bölümden oluşmuştur. Birinci bölüm, tüketici sağlığı bilişimine yönelik 47 ifade için 5’li Likert tipi ölçek kullanılmış olup "1: Hiç Katılmıyorum”, “2: Katılıyorum”, “3: Ne Katılıyorum Ne Katılmıyorum”, “4: Katılıyorum”, “5: Tamamen Katılıorum” şeklinde derecelendirilmiştir. Anketin ikinci bölümünde güncel sağlık teknolojilerindeki sorunlar ile ilgili açık uçlu soru yer almaktadır. Son bölümünde yaş, cinsiyet, eğitim düzeyi gibi demografik değişkenler bulunmaktadır.

\section{Analiz ve Yöntem}

Anket formları aracılığıyla elde edilen veriler Statistical Package for the Social Sciences (SPSS 22.0) programı kullanılarak analiz edilmiş öncelikle açıklayıcı faktör analizine tabii tutulmuştur. Güvenilirliği düşüren, teorik çerçeveye uymayan ve bir boyutta iki ifadenin kaldığı durumlarda bazı ifadeler faktör analizi aşamasında analizden çıkartılmıştır. Faktör analizi yapılırken varimax döndürme işlemi yapılmıştır. Analiz sonucunda soruların 7 boyutta toplandı̆̆ 1 tespit edilmiştir. Anketten elde edilen veriler aritmetik ortalama, standart sapma, frekans ve yüzde hesaplamaları ile analiz edilmiş ve istatistiksel değerlendirmeler bu puan ortalamaları üzerinden yapılmıştır. Daha sonra veriler normallik testine tabi tutulmuştur. Verilerin normal dağılıma 
uygun olup olmadığını tespit etmek için her bir boyutun çarpıklık ve basıklık değerleri incelenmiştir (Tablo 3). Bütün boyutlarda verilerin normal dağılım gösterdiği tespit edildikten sonra parametrik testler yapılmıştır. Parametrik testlerden ikili grupların karşılaştırılmasında "t-testi"; üç ve üzeri grupların karşılaştırılmasında "ANOVA (varyans analizi) testi" kullanılmıştır. Varyans analizi sonucunda gruplar arasında fark bulunduğunda, farkın kaynağı “Tukey's-b testi” ile tespit edilmiştir.

\section{Bulgular}

\section{Demografik Bulgular}

Çalışmanın sosyo-demografik özelliklerinde kuşakların tarih ayrımı yapılırken literatürde ortak bir kullanıma rastlanmamıştır. Bu nedenle Lancaster ve Stillman'ın (2002) X kuşağı için 19651980 (54-39), Y kuşağı için 1981-1999 (38-20) ve Z kuşağı için 2000 ve sonrası yıllar sınıflandırması dikkate alınarak kuşakların tarih aralıklar belirlenmiştir. Çalışmaya katılan bireylerin demografik değişkenlere göre dağılımı Tablo 1'de gösterilmiştir.

Tablo 1. Katılımcıların Demografik Değerlere Göre Dă̆ılımı

\begin{tabular}{|c|c|c|}
\hline Değişkenler & Frekans & Yüzde \\
\hline \multicolumn{3}{|l|}{ Kuşak } \\
\hline $\mathrm{X}$ & 90 & 20.9 \\
\hline $\mathrm{Y}$ & 168 & 39.0 \\
\hline $\mathrm{Z}$ & 173 & 40.1 \\
\hline \multicolumn{3}{|l|}{ Cinsiyet } \\
\hline Kadın & 243 & 55.2 \\
\hline Erkek & 197 & 44.8 \\
\hline \multicolumn{3}{|l|}{ Medeni Durumu } \\
\hline Evli & 126 & 28.6 \\
\hline Evli Değil & 315 & 71.4 \\
\hline \multicolumn{3}{|l|}{ Eğitim Durumu } \\
\hline Temel Eğitim & 90 & 20.5 \\
\hline Ön Lisans & 71 & 16.2 \\
\hline Lisans & 235 & 53.5 \\
\hline Lisansüstü & 43 & 9.8 \\
\hline \multicolumn{3}{|l|}{ Aylık Gelir (TL) } \\
\hline-999 & 101 & 28.5 \\
\hline $1000-1999$ & 71 & 20.1 \\
\hline $2000-2999$ & 46 & 13.0 \\
\hline 3000-3999 & 38 & 10.7 \\
\hline $4000+$ & 98 & 27.7 \\
\hline \multicolumn{3}{|c|}{ Çalışma Durumu } \\
\hline Kamu Sektörü & 108 & 24.5 \\
\hline Özel Sektör & 70 & 15.9 \\
\hline Öğrenci & 262 & 59.5 \\
\hline
\end{tabular}


Tablo1'de görüldüğü üzere, katılımcıların \%55.2'si kadınlardan, \%44.8'i ise erkeklerden oluşmaktadır. Katılımcıların \%20.9'u X kuşağı, \%39.0'1 Y kuşağı ve \%40.1'i ise Z kuşağıdır. Medeni durumlarına göre bakıldığında katılımcıların yarıdan fazlasının (71.4) evli olmadığı görülmektedir. Katılımcıların eğitim düzeyleri incelendiğinde \%20.5'inin temel eğitime (ilköğretim, ortaöğretim, lise) tabi olduğu, \%16.2'sinin ön lisans, \%53.5’inin lisans ve \%9.8'inin lisansüstü eğitim düzeyine sahip olduğu görülmektedir.

Araştırmaya katılan bireylerin gelir durumu incelendiğinde \%28.5'inin 0-999 TL arasında, \%20.1'inin 1000-1999 TL arasında, \%13'ünün 2000-2999 TL arasında, \%10.7'sinin 3000-3999 TL arasında ve \%27.7’sinin 4000 ve üzerinde olduğu görülmektedir. Son olarak katılımcıların görev dağılımına bakıldığında ise \%24.5’inin kamu sektöründe, \%15.9'unun özel sektörde çalışmakta olduğu ve \%59.5’inin ise öğrenci olduğu ortaya çıkmıştır.

\section{Tüketici Sağlığı Bilişimi Faktör Analizi}

Çalışma anketi araştırmacı tarafından oluşturulduğu için veriler faktör analizine tabi tutulmuştur. Analizde Varimax döndürme yöntemi kullanılmış, faktör yükü 0.30'dan düşük ifadeler, 0.10 'dan daha az farkla birden fazla faktöre dâhil olan binişik ifadeler, teoriye uymayan ifadeler ve bir boyutta iki ifade kaldığı için bu ifadeler boyutlardan çıkarılmıştır. Faktör analizine dair sonuçlar Tablo 2'de gösterilmektedir.

Tablo 2. Sağlık Hizmetlerinde Sağlık Teknolojilerinin Değerlendirilmesine İlişkin Faktör Analizi

\begin{tabular}{|c|c|c|c|}
\hline \multicolumn{4}{|c|}{ 1.Faktör: Fayda Algısı } \\
\hline 30 & Giyilebilir teknolojileri faydalı buluyorum. & 0.813 & \multirow{8}{*}{14.536} \\
\hline 27 & Teletıbbı faydalı buluyorum. & 0.794 & \\
\hline 31 & Robotik teknolojileri faydalı buluyorum. & 0.776 & \\
\hline 29 & İlaç takip sistemini faydalı buluyorum. & 0.747 & \\
\hline 26 & e-Nabızı faydalı buluyorum. & 0.736 & \\
\hline 33 & Sağlık problemlerimde yapay zekâ teknolojilerini faydalı buluyorum. & 0.728 & \\
\hline 25 & Mobil sağlık teknolojilerini faydalı buluyorum. & 0.727 & \\
\hline 24 & Sağlık teknolojilerini faydalı buluyorum. & 0.664 & \\
\hline \multicolumn{4}{|c|}{ 2. Faktör: Sağlıkta İleri Teknoloji Kullanımı Beklentisi } \\
\hline 44 & $\begin{array}{l}\text { Gelecekte hastayı yönlendirici ilaç yönetim ve ilk yardım çağrısı için } \\
\text { konuşabilen cihazların kullanılacağını düşünüyorum. }\end{array}$ & 0.828 & \multirow{6}{*}{13.736} \\
\hline 45 & $\begin{array}{l}\text { Gelecekte akıllı hapların vücuttaki sorunun yerini ve boyutunu } \\
\text { tespit etmede daha sık kullanılacağını düşünüyorum. }\end{array}$ & 0.754 & \\
\hline 47 & $\begin{array}{l}\text { Gelecekte cerrahi işlemlerde Robo-doktorların daha sık } \\
\text { kullanılacağını düşünüyorum. }\end{array}$ & 0.730 & \\
\hline 42 & $\begin{array}{l}\text { Gelecekte sağlı̆̆ı yönlendirici sanal doktorların kullanılacağını } \\
\text { düşünüyorum. }\end{array}$ & 0.717 & \\
\hline 46 & $\begin{array}{l}\text { Gelecekte kişinin ciddi hastalıklarının yıllar öncesinden tespit } \\
\text { edilebileceğini düşünüyorum. }\end{array}$ & 0.712 & \\
\hline 41 & $\begin{array}{l}\text { Gelecekte tahlil, tetkik, MR, EKG, vb. işlemlerin taşınabilir } \\
\text { cihazlarla yapılabileceğini düşünüyorum. }\end{array}$ & 0.697 & \\
\hline
\end{tabular}




\begin{tabular}{|c|c|c|c|}
\hline 40 & $\begin{array}{l}\text { Gelecekte uzaktan izleme yönteminin yaygın olarak kullanılacağını } \\
\text { düşünüyorum. }\end{array}$ & 0.686 & \\
\hline 43 & $\begin{array}{l}\text { Gelecekte, giyilebilir teknolojilerin daha sık kullanılacağını } \\
\text { düşünüyorum. }\end{array}$ & 0.666 & \\
\hline \multicolumn{4}{|c|}{ 3. Faktör: Sağlık Teknolojileri Okuryazarlığı } \\
\hline 20 & Sağlığımla ilgili konularda sosyal medya kullanıyorum. & 0.802 & \multirow{6}{*}{10.085} \\
\hline 9 & Sağllğımla ilgili konularda sosyal medya araçlarını biliyorum. & 0.746 & \\
\hline 22 & Sağlık teknolojilerini akıllı telefon üzerinden kullanıyorum. & 0.733 & \\
\hline 21 & Sağlık teknolojilerini web üzerinden kullanıyorum. & 0.701 & \\
\hline 10 & Sağlığımı iyileştirmede sağlık teknolojilerini kullanmayı biliyorum. & 0.596 & \\
\hline 1 & Sağlığımı iyileştirmede sağlık teknolojilerinden faydalanıyorum. & 0.534 & \\
\hline \multicolumn{4}{|c|}{ 4. Faktör: Sağlıkta İleri Teknoloji Bilgisi } \\
\hline 8 & Robotik teknolojileri biliyorum. & 0.791 & \multirow{4}{*}{7.853} \\
\hline 7 & Giyilebilir teknolojileri biliyorum. & 0.771 & \\
\hline 12 & $\begin{array}{l}\text { Sağlık hizmetleri için geliştirilen yapay zekâ uygulamaları (Sanal } \\
\text { robot, hasta veri analizi, erken teşhis, otomatik teşhis ve reçete, } \\
\text { kişiselleştirilmiş ilaç ve tedavi, tıbbi görüntüleme ile çözüm, gen } \\
\text { analizi, vb.) hakkında bilgi sahibiyim. }\end{array}$ & 0.601 & \\
\hline 11 & $\begin{array}{l}\text { Yapay zekâ (akıllı makineler üretme bilimi ve mühendisliği, akıllı } \\
\text { bilgisayar programları) hakkında bilgi sahibiyim. }\end{array}$ & 0.591 & \\
\hline \multicolumn{4}{|c|}{ 5. Faktör: MHRS Bilgisi ve Kullanımı } \\
\hline 16 & MHRS’yi (Alo 182) kullanıyorum. & 0.860 & \multirow{3}{*}{6.742} \\
\hline 5 & Sağlık Bakanlığının MHRS (Alo 182) uygulamasını biliyorum. & 0.847 & \\
\hline 28 & MHRS’yi (Alo 182) faydalı buluyorum. & 0.727 & \\
\hline \multicolumn{4}{|c|}{ 6. Faktör: e-Nabız ve Mobil Sağlık Uygulaması Bilgisi } \\
\hline 3 & Sağlık Bakanlığının e-Nabız uygulamasını biliyorum. & 0.810 & \multirow{3}{*}{6.483} \\
\hline 15 & e-Nabızı kullanıyorum. & 0.790 & \\
\hline 2 & e-Sağlık kapsamında Mobil Sağlık uygulamalarını biliyorum. & 0.637 & \\
\hline \multicolumn{4}{|c|}{ 7. Faktör: Hastaneye Duyulan İhtiyacın Azalması } \\
\hline 38 & Gelecekte hekimlere daha az ihtiyaç duyulacağını düşünüyorum. & 0.827 & \multirow{3}{*}{6.027} \\
\hline 39 & $\begin{array}{l}\text { Yapay zekâ uygulamaları ile sağlık sorunlarıma kendim tanı } \\
\text { koyabileceğimi düşünüyorum. }\end{array}$ & 0.772 & \\
\hline 37 & Gelecekte hastanelere daha az gidileceğini düşünüyorum. & 0.716 & \\
\hline
\end{tabular}

Tablo 2'de tüketici sağlığı bilişimi teknolojilerinin değerlendirilmesi anketinde 7 boyutun faktör yükleri verilmiştir. Örneklem büyüklügü yeterliliği, verilen faktör analizine uygunluğu ve değişkenler arasındaki korelasyonun anlamlılığı için KMO (Kaiser-Meyer-Olkin) değeri 0.883 olarak bulunmuş ve Bartlett testi yapılmıştır. Barlett testi sonucunda değişkenler arası korelasyonun $\mathrm{p}<0.00$ düzeyinde anlamlı olduğu anlaşılmıştır.

\section{Boyutların Psikometrik Özellikleri}

Araştırmada bireylerin tüketici sağlığı bilişimi teknolojilerinin değerlendirilmesi anketi sonucunda her bir boyutun aldığ 1 değerler Tablo 3'te gösterilmiştir. 
Tablo 3. Boyutların Psikometrik Özellikleri

\begin{tabular}{|c|c|c|c|c|c|c|c|}
\hline \multirow[b]{2}{*}{ Boyutlar } & \multirow[b]{2}{*}{$\begin{array}{l}\text { İfade } \\
\text { Sayısı }\end{array}$} & \multirow[b]{2}{*}{$\begin{array}{l}\text { Max- } \\
\text { Min }\end{array}$} & \multirow[b]{2}{*}{$\begin{array}{c}\text { Cronbach } \\
\text { Alfa }\end{array}$} & \multirow[b]{2}{*}{$\bar{X}$} & \multirow[b]{2}{*}{ SS } & \multicolumn{2}{|c|}{ Normallik Testi } \\
\hline & & & & & & $\begin{array}{c}\text { Kurtosis } \\
\text { (Basıklık) }\end{array}$ & $\begin{array}{c}\text { Skewness } \\
\text { (Çarpıklık) }\end{array}$ \\
\hline $\begin{array}{l}\text { Fayda Alg1s1 } \\
\text { Boyutu }\end{array}$ & 8 & $1-5$ & 0.910 & 3.698 & 1.005 & -0.626 & -0.422 \\
\hline $\begin{array}{l}\text { Sağlıkta İleri } \\
\text { Teknoloji } \\
\text { Kullanımı } \\
\text { Beklentisi Boyutu }\end{array}$ & 8 & $1-5$ & 0.896 & 3.569 & 0.963 & -0.369 & -0.462 \\
\hline $\begin{array}{l}\text { Sağlık Teknolojileri } \\
\text { Okuryazarlığ } \\
\text { Boyutu }\end{array}$ & 6 & $1-5$ & 0.839 & 3.145 & 1.002 & -0.710 & -0.021 \\
\hline $\begin{array}{l}\text { Sağllkta İleri } \\
\text { Teknoloji Bilgisi } \\
\text { Boyutu }\end{array}$ & 4 & $1-5$ & 0.802 & 2.668 & 1.086 & -0.585 & 0.368 \\
\hline $\begin{array}{l}\text { MHRS Bilgisi ve } \\
\text { Kullanım1 Boyutu }\end{array}$ & 3 & $1-5$ & 0.822 & 2.868 & 1.225 & -0.958 & 0.241 \\
\hline $\begin{array}{l}\text { e-Nabiz ve Mobil } \\
\text { Sağlık Uygulaması } \\
\text { Bilgisi Boyutu }\end{array}$ & 3 & $1-5$ & 0.768 & 3.978 & 1.217 & -0.382 & -0.944 \\
\hline $\begin{array}{l}\text { Hastaneye Duyulan } \\
\text { İhtiyacın Azalması } \\
\text { Boyutu }\end{array}$ & 3 & $1-5$ & 0.765 & 2.722 & 1.171 & -0.965 & 0.173 \\
\hline
\end{tabular}

Tablo 3'te verilen her bir boyuta ait bilgiler şöyledir:

Fayda Algısı Boyutu: Boyut, 8 ifadeden oluşmaktadır. Bu boyutta katılımcıların tüketici sağlı̆̆ı bilişimi teknolojilerini faydalı bulup bulmadıkları değerlendirilmiştir. Fayda algısı boyutunun aritmetik ortalaması 3.698 ve standart sapması 1.005 olarak bulunmuştur. Boyutun güvenilirlik derecesi (Cronbach Alpha) ise 0.910 olarak görülmektedir. Bu boyut yüksek derecede güvenilir bulunmuştur.

Sağlıkta İleri Teknoloji Kullanımı Beklentisi Boyutu: Bu boyut 8 ifadeden oluşmaktadır. Bu boyutta katılımcıların gelecekte tüketici sağlığı bilişimi teknolojilerinden beklentileri değerlendirilmiştir. Sağlıkta ileri teknoloji kullanımı boyutunun aritmetik ortalaması 3.569 ve standart sapması 0.963 olarak bulunmuştur. Boyutun güvenilirlik derecesi ise 0.896 olarak görülmektedir. Bu boyut yüksek derecede güvenilir bulunmuştur.

Sağlık Teknolojileri Okuryazarlı̆̆ı Boyutu: Bu boyut 6 ifadeden oluşmaktadır. Bu boyutta ile katılımcıların tüketici sağlığı bilişimi teknolojileri hakkında bilgi edinmek için hangi yollara başvurdukları değerlendirilmiştir. Sağlık teknolojileri okuryazarlığı boyutunun aritmetik ortalaması 3.145 ve standart sapması 1.002 olarak bulunmuştur. Boyutun güvenilirlik derecesi ise 0.839 olarak görülmektedir. Bu boyut yüksek derecede güvenilir bulunmuştur.

Sağlıkta İleri Teknoloji Bilgisi Boyutu: Bu boyut 4 ifadeden oluşmaktadır. Bu boyutta katılımcıların tüketici sağlı̆̆ bilişimindeki ileri düzey teknolojiler hakkında bilgilerinin olup olmadığı değerlendirilmiştir. Sağlıkta ileri teknoloji bilgisi boyutunun aritmetik ortalaması 2.668 ve standart sapması 1.086 olarak bulunmuştur. Boyutun güvenilirlik derecesi ise 0.802 olarak görülmektedir. Bu boyut yüksek derecede güvenilir bulunmuştur. 
MHRS Bilgisi ve Kullanımı Boyutu: Boyut, 3 ifadeden oluşmaktadır. Bu boyutta katılımcıların MHRS uygulamasına dair bilgi ve kullanım düzeyleri değerlendirilmiştir. MHRS bilgisi ve kullanımı boyutunun aritmetik ortalaması 2.868 ve standart sapması 1.225 olarak bulunmuştur. Boyutun güvenilirlik derecesi ise 0.822 olarak görülmektedir. Bu boyut yüksek derecede güvenilir bulunmuştur.

e-Nabız ve Mobil Sağlık Uygulaması Bilgisi Boyutu: Bu boyut 3 ifadeden oluşmaktadır. Bu boyuttaki ifadeler ile katılımcıların bir tüketici sağlığı bilişimi teknolojisi olan e-Nabız ve mobil sağlık uygulamaları dair bilgi sahibi olup olmadıkları değerlendirilmiştir. e-Nabız ve mobil sağlık uygulaması bilgisi boyutunun aritmetik ortalaması 3.978 ve standart sapması 1.217 olarak bulunmuştur. Boyutun güvenilirlik derecesi 0.822 olarak görülmektedir. Bu boyut yüksek derecede güvenilir bulunmuştur.

Hastaneye Duyulan İhtiyacın Azalması Boyutu: Bu boyut 3 ifadeden oluşmaktadır. Bu boyuttaki ifadeler ile katılımcıların sağlık hizmetlerinde hastaneye duyulan ihtiyacın azalması yönünde değerlendirmeleri incelenmiştir. Hastaneye duyulan ihtiyacın azalması boyutunun aritmetik ortalaması 2.722 ve standart sapması 1.171 olarak bulunmuştur. Boyutun güvenilirlik derecesi (Cronbach Alpha) ise 0.765 olarak güvenilir bulunmuştur.

Araştırmalar sonucu elde edilen veri setinin normal dağılım sergileyip sergilemediğini yorumlayabilmek için basıklık ve çarpıklık katsayılarının -1 ile +1 arasında bir değer alması gerekmektedir (Morgan vd. 2011: s. 51). Tablo 3’e bakıldığında bu çalışmanın basıklık ve çarpıklık katsayılarının -1 ile +1 arasında değerlerler aldı̆̆ı görülmektedir. Bu sebeple veri setinin normal dağılıma uygun olduğu görülmüş ve verilerin analizinde parametrik testler kullanılmıştır.

\section{Boyutların Demografik Değişkenlere Göre Karşılaştırılması}

\section{Fayda Algısı Boyutunun Demografik Değişkenlere Göre Karşılaştırılması}

Fayda algısı boyutunun aldığı puanların demografik değişkenlere göre dağılımı Tablo 4'te verilmiştir.

Fayda algısı boyutunun puanları kuşaklarına göre karşılaştırıldığında, istatistiksel olarak anlamlı bir farklılık olduğu tespit edilmiştir $(\mathrm{F}=4.097, \mathrm{p}=0.017)$. 
Tablo 4. Fayda Algısı Boyutunun Demografik Değişkenlere Göre Karşılaştırılması

\begin{tabular}{|c|c|c|c|c|}
\hline Değişkenler & $\mathbf{N}$ & $\bar{X}$ & SS & Test Değerleri \\
\hline \multicolumn{5}{|l|}{ Kușak } \\
\hline $\mathrm{X}$ & 90 & 3.545 & 0.119 & \multirow{3}{*}{$\begin{array}{l}F=4.097 \\
p=0.017\end{array}$} \\
\hline $\bar{Y}$ & 168 & 3.864 & 0.071 & \\
\hline $\mathrm{Z}$ & 170 & 3.610 & 0.745 & \\
\hline \multicolumn{5}{|l|}{ Cinsiyet } \\
\hline Kadın & 243 & 3.617 & 1.019 & \multirow{2}{*}{$\begin{array}{l}\mathrm{t}=-1.967 \\
\mathrm{p}=0.150\end{array}$} \\
\hline Erkek & 197 & 3.805 & 0.975 & \\
\hline \multicolumn{5}{|l|}{ Medeni Durum } \\
\hline Evli & 126 & 3.737 & 1.068 & \multirow{2}{*}{$\begin{array}{l}\mathrm{t}=0.518 \\
\mathrm{p}=0.605\end{array}$} \\
\hline Evli Değil & 315 & 3.682 & 0.980 & \\
\hline \multicolumn{5}{|l|}{ Eğitim Durumu } \\
\hline Temel Eğitim & 90 & 3.542 & 1.071 & \multirow{4}{*}{$\begin{array}{l}F=1.423 \\
p=0.235\end{array}$} \\
\hline Ön Lisans & 71 & 3.685 & 0.987 & \\
\hline Lisans & 235 & 3.725 & 0.978 & \\
\hline Lisansüstü & 43 & 3.909 & 1.017 & \\
\hline \multicolumn{5}{|l|}{ Aylık Gelir (TL) } \\
\hline-999 & 101 & 3.671 & 0.977 & \multirow{5}{*}{$\begin{array}{l}\mathrm{F}=2.588 \\
\mathrm{P}=0.037\end{array}$} \\
\hline $1000-1999$ & 71 & 3.758 & 0.883 & \\
\hline $2000-2999$ & 46 & 3.512 & 1.067 & \\
\hline $3000-3999$ & 38 & 3.370 & 1.057 & \\
\hline $4000+$ & 98 & 3.911 & 1.064 & \\
\hline \multicolumn{5}{|l|}{ Çalıșma Durumu } \\
\hline Kamu Sektörü & 108 & 3.739 & 1.089 & \multirow{3}{*}{$\begin{array}{l}F=0.122 \\
p=0.885\end{array}$} \\
\hline Özel Sektör & 70 & 3.706 & 1.089 & \\
\hline Ögrenci & 262 & 3.683 & 0.946 & \\
\hline
\end{tabular}

Tukey's-b testi sonucunda farkın X kuşağının fayda algısından aldığı puanın, Y kuşağının fayda algısından aldığı puandan düşük olmasından kaynaklandığı anlaşılmıştır. Y kuşağının X ve Z kuşağına göre sağlık hizmetlerinde tüketici sağlı̆̆ı bilişimi kullanımındaki fayda düzeylerinin daha yüksek olduğu söylenebilir. Bunun yanı sıra fayda algısı boyutu katılımcıların aylık gelir durumuna göre karşılaştırıldığında istatistiksel olarak anlamlı bir fark olduğu bulunmuştur ( $\mathrm{F}=$ 2.588, $\mathrm{P}=0.037$ ). Yapilan ileri analizde bunun nedeninin 3000-3999 arasi gelir alanlar ile 4000 ve üstü gelir alanlar arasında olduğu görülmüştür. 4000 ve üzeri gelire sahip olan katılımcıların 3999 ve altı gelire sahip katılımcılara göre tüketici sağlı̆̆ bilişimini daha faydalı bulduğu söylenebilir.

\section{Sağlıkta ileri Teknoloji Kullanımı Beklentisi Boyutunun Demografik Değişkenlere Göre Karşılaştırılması}

Sağlıkta ileri teknoloji kullanımı beklentisi boyutunun demografik değişkenlere göre dağılımı Tablo 5'te verilmiştir.

Sağlıkta ileri teknoloji kullanımı beklentisi boyutunun puanları katılımcıların cinsiyetine göre karşılaştırıldığında anlamlı bir farklılık olduğu ortaya çıkmıştır $(\mathrm{t}=-3.588, \mathrm{p}=0.000)$. 
Tablo 5. Sağlıkta İleri Teknoloji Kullanımı Beklentisi Boyutunun Demografik Değişkenlere Göre Karşılaştırılması

\begin{tabular}{|c|c|c|c|c|}
\hline Değişkenler & $\mathbf{N}$ & $\bar{X}$ & SS & Test Değerleri \\
\hline \multicolumn{5}{|l|}{ Kușak } \\
\hline $\mathrm{X}$ & 90 & 3.391 & 1.133 & \multirow{3}{*}{$\begin{array}{l}F=2.793 \\
p=0.062\end{array}$} \\
\hline $\mathrm{Y}$ & 168 & 3.683 & 0.911 & \\
\hline $\mathrm{Z}$ & 173 & 3.562 & 0.874 & \\
\hline \multicolumn{5}{|l|}{ Cinsiyet } \\
\hline Kadın & 243 & 3.428 & 0.941 & \multirow{2}{*}{$\begin{array}{l}\mathrm{t}=-3.588 \\
\mathrm{p}=0.000\end{array}$} \\
\hline Erkek & 197 & 3.754 & 0.952 & \\
\hline \multicolumn{5}{|l|}{ Medeni Durum } \\
\hline Evli & 126 & 3.433 & 1.108 & \multirow{2}{*}{$\begin{array}{l}t=-1.711 \\
p=0.089\end{array}$} \\
\hline Evli Değil & 315 & 3.623 & 0.895 & \\
\hline \multicolumn{5}{|l|}{ Eğitim Durumu } \\
\hline Temel Eğitim & 90 & 3.457 & 0.919 & \multirow{4}{*}{$\begin{array}{l}\mathrm{F}=2.290 \\
\mathrm{p}=0.078\end{array}$} \\
\hline Ön Lisans & 71 & 3.657 & 0.911 & \\
\hline Lisans & 235 & 3.528 & 0.975 & \\
\hline Lisansüstü & 43 & 3.882 & 0.998 & \\
\hline \multicolumn{5}{|l|}{ Aylık Gelir (TL) } \\
\hline-999 & 101 & 3.607 & 0.904 & \multirow{5}{*}{$\begin{array}{l}\mathrm{F}=2.411 \\
\mathrm{P}=0.046\end{array}$} \\
\hline $1000-1999$ & 71 & 3.628 & 0.927 & \\
\hline $2000-2999$ & 46 & 3.294 & 1.052 & \\
\hline $3000-3999$ & 38 & 3.273 & 0.981 & \\
\hline $4000+$ & 98 & 3.726 & 1.094 & \\
\hline \multicolumn{5}{|l|}{ Çalışma Durumu } \\
\hline Kamu Sektörü & 108 & 3.571 & 1.083 & \multirow{3}{*}{$\begin{array}{l}F=0.402 \\
p=0.669\end{array}$} \\
\hline Özel Sektör & 70 & 3.483 & 1.035 & \\
\hline Öğrenci & 262 & 3.599 & 0.882 & \\
\hline
\end{tabular}

Buradan hareketle erkeklerin ileri teknolojileri gelecekte kullanmak istedikleri söylenebilir. Bunun yanı sıra boyutunun katılımcıların aylık gelir durumuna göre karşılaştırıldığında istatistiksel olarak anlamlı bir fark olduğu görülmüştür $(\mathrm{F}=2.411, \mathrm{P}=0.046)$. Tukey’s-b testi sonucunda farkın 2000-2999 arası gelire sahip olanlarla 3000-3999 arası gelire sahip olanlar ve 4000 ve üzeri gelire sahip olanlar arasında olduğu sonucuna ulaşılmıştır. Gelecekte geliri 4000 ve üzerinde yüksek olan bireylerin sağlıkta ileri teknolojileri daha çok kullanacağı söylenebilir.

\section{Sağlık Teknolojileri Okuryazarlığı Boyutunun Demografik Değişkenlere Göre Karşılaştırılması}

Sağlık teknolojileri okuryazarlığı boyutunun demografi değişkenlere göre dağılımı Tablo 6' da verilmiştir.

Tablo 6'da görüldüğü üzere sağlık teknolojisi okuryazarlığı boyutunun katılımcıların cinsiyet $(\mathrm{t}=0.294, \mathrm{p}=0.769)$, yaş $(\mathrm{F}=2.097, \mathrm{p}=0.124)$, medeni durum $(\mathrm{t}=-1.269, \mathrm{p}=0.206)$, eğitim durumu $(\mathrm{F}=0.360, \mathrm{p}=0.782)$, aylık gelir $(\mathrm{F}=1.288, \mathrm{P}=0.274)$ ve çalışma durumuna $(\mathrm{F}=0.830$, $\mathrm{p}=0.162)$ göre karşılaştırıldığında istatistiksel olarak anlamlı bir fark bulunmamıştır. 
Tablo 6. Sağlık Teknolojileri Okuryazarlı̆̆ı Boyutunun Demografik Değişkenlere Göre Karşılaştırılması

\begin{tabular}{|c|c|c|c|c|}
\hline Değişkenler & $\mathbf{N}$ & $\bar{X}$ & SS & Test Değerleri \\
\hline \multicolumn{5}{|l|}{ Kuşak } \\
\hline $\mathrm{X}$ & 90 & 2.991 & 1.052 & \multirow{3}{*}{$\begin{array}{l}F=2.097 \\
p=0.124\end{array}$} \\
\hline $\mathrm{Y}$ & 168 & 3.254 & 0.967 & \\
\hline $\mathrm{Z}$ & 173 & 3.154 & 0.962 & \\
\hline \multicolumn{5}{|l|}{ Cinsiyet } \\
\hline Kadın & 243 & 3.161 & 1.006 & \multirow{2}{*}{$\begin{aligned} \mathrm{t} & =0.294 \\
\mathrm{p} & =0.769\end{aligned}$} \\
\hline Erkek & 197 & 3.133 & 0.994 & \\
\hline \multicolumn{5}{|l|}{ Medeni Durum } \\
\hline Evli & 126 & 3.043 & 1.100 & \multirow{2}{*}{$\begin{array}{l}\mathrm{t}=-1.269 \\
\mathrm{p}=0.206\end{array}$} \\
\hline Evli Değil & 315 & 3.185 & 0.959 & \\
\hline \multicolumn{5}{|l|}{ Eğitim Durumu } \\
\hline Temel Eğitim & 90 & 3.097 & 1.049 & \multirow{4}{*}{$\begin{array}{l}F=0.360 \\
p=0.782\end{array}$} \\
\hline Ön Lisans & 71 & 3.248 & 0.995 & \\
\hline Lisans & 235 & 3.126 & 0.961 & \\
\hline Lisansüstü & 43 & 3.178 & 1.132 & \\
\hline \multicolumn{5}{|l|}{ Aylık Gelir (TL) } \\
\hline-999 & 101 & 3.047 & 0.945 & \multirow{5}{*}{$\begin{array}{l}\mathrm{F}=1.288 \\
\mathrm{P}=0.274\end{array}$} \\
\hline $1000-1999$ & 71 & 3.346 & 0.903 & \\
\hline $2000-2999$ & 46 & 3.142 & 0.954 & \\
\hline $3000-3999$ & 38 & 3.051 & 1.045 & \\
\hline $4000+$ & 98 & 3.023 & 1.156 & \\
\hline \multicolumn{5}{|l|}{ Çalışma Durumu } \\
\hline Kamu Sektörü & 108 & 2.990 & 1.129 & \multirow{3}{*}{$\begin{array}{l}F=0.830 \\
p=0.162\end{array}$} \\
\hline Özel Sektör & 70 & 3.163 & 1.048 & \\
\hline Öğrenci & 262 & 3.208 & 0.929 & \\
\hline
\end{tabular}

Sağlıkta ileri Teknoloji Bilgisi Boyutunun Demografik Değişkenlere Göre Karşılaştırılması

Sağlıkta ileri teknoloji bilgisi boyutunun demografi değişkenlere göre dağılımı Tablo 7’de verilmiştir. 
Tablo 7. Sağlıkta İleri Teknoloji Bilgisi Boyutunun Demografik Değişkenlere Göre Karşılaştırılması

\begin{tabular}{|c|c|c|c|c|}
\hline Değiş̧kenler & $\mathbf{N}$ & $\bar{X}$ & SS & Test Değerleri \\
\hline \multicolumn{5}{|l|}{ Kuşak } \\
\hline $\mathrm{X}$ & 90 & 2.575 & 1.187 & \multirow{3}{*}{$\begin{array}{l}F=4.717 \\
p=0.009\end{array}$} \\
\hline $\bar{Y}$ & 168 & 2.867 & 1.073 & \\
\hline $\mathrm{Z}$ & 173 & 2.670 & 0.990 & \\
\hline \multicolumn{5}{|l|}{ Cinsiyet } \\
\hline Kadın & 243 & 2.445 & 0.997 & \multirow{2}{*}{$\begin{array}{l}\mathrm{t}=-4.915 \\
\mathrm{p}=0.000\end{array}$} \\
\hline Erkek & 197 & 2.949 & 1.126 & \\
\hline \multicolumn{5}{|l|}{ Medeni Durum } \\
\hline Evli & 126 & 2.570 & 1.181 & \multirow{2}{*}{$\begin{array}{l}\mathrm{t}=-1.129 \\
\mathrm{p}=0.260\end{array}$} \\
\hline Evli Değil & 315 & 2.706 & 1.045 & \\
\hline \multicolumn{5}{|l|}{ Eğitim Durumu } \\
\hline Temel Eğitim & 90 & 2.444 & 1.047 & \multirow{4}{*}{$\begin{array}{l}F=5.094 \\
p=0.002\end{array}$} \\
\hline Ön Lisans & 71 & 2.644 & 1.157 & \\
\hline Lisans & 235 & 2.661 & 1.029 & \\
\hline Lisansüstü & 43 & 3.219 & 1.211 & \\
\hline \multicolumn{5}{|l|}{ Aylık Gelir (TL) } \\
\hline-999 & 101 & 2.587 & 0.993 & \multirow{5}{*}{$\begin{array}{l}F=1.901 \\
P=0.101\end{array}$} \\
\hline 1000-1999 & 71 & 2.915 & 0.992 & \\
\hline $2000-2999$ & 46 & 2.516 & 1.008 & \\
\hline $3000-3999$ & 38 & 2.572 & 1.070 & \\
\hline $4000+$ & 98 & 2.858 & 1.294 & \\
\hline \multicolumn{5}{|l|}{ Çalışma Durumu } \\
\hline Kamu Sektörü & 108 & 2.723 & 1.239 & \multirow{3}{*}{$\begin{array}{l}F=0.215 \\
p=0.807\end{array}$} \\
\hline Özel Sektör & 70 & 2.683 & 1.145 & \\
\hline Öğrenci & 262 & 2.643 & 1.004 & \\
\hline
\end{tabular}

Sağlı ileri teknoloji bilgisi boyutunun puanları katılımcıların cinsiyetine göre karşılaştırıldığında anlamlı bir fark olduğu bulunmuştur $(\mathrm{t}=-4.915, \mathrm{p}=0.000)$. Bu nedenle erkek katılımcıların kadın katılımcılara göre sağlıktaki ileri düzey teknolojilerden daha fazla doyum sağladı̆̆ı söylenebilir.

Bunun yanı sıra sağlıkta ileri teknoloji bilgisi boyutunun puanları katılımcıların kuşaklarına göre karşılaştırıldığında kuşaklar arasında istatistiksel olarak anlamlı bir fark olduğu bulunmuştur ( $F=4.717, \mathrm{p}=0.009)$. Tukey's-b testi sonucunda farkın $\mathrm{Y}$ kuşağı bireylerinin $\mathrm{X}$ ve Z kuşağı bireylerine göre yüksek puan almasından kaynaklandığı tespit edilmiştir.

Bu noktada Y kuşağı bireylerinin sağlıkta ileri teknoloji bilgisinin X ve Z kuşaklarına göre daha fazla olduğu söylenebilir. Sağlık ileri teknoloji bilgisi boyutunun puanları katılımcıların eğitim durumuna göre karşılaştırıldığında eğitim durumu arttıkça ileri teknoloji bilgisinden aldıkları puanlar da artış eğilimi göstermiş ve gruplar arasında istatistiksel olarak anlamlı bir farklılık olduğu tespit edilmiştir ( $\mathrm{F}=5.094, \mathrm{p}=0.002)$.

İleri analizler sonucunda farkın lisansüstü eğitime sahip bireylerin en yüksek değeri almasından kaynaklandığı ortaya çıkmıştır. Bu noktada eğitim seviyesi yüksek olan kişilerin sağlıkta ileri teknoloji bilgisinin yüksek olduğu söylenebilir.

\section{MHRS Bilgisi ve Kullanımı Boyutunun Demografik Değişkenlere Göre Karşılaştırılması}

MHRS bilgisi ve kullanılması boyutunun demografi değişkenlere göre dağılımı Tablo 8'de verilmiştir. 
Tablo 8. MHRS Bilgisi ve Kullanımı Boyutunun Demografik Değişkenlere Göre Karşılaştırılması

\begin{tabular}{|c|c|c|c|c|}
\hline Değişkenler & $\mathbf{N}$ & $\bar{X}$ & SS & Test Değerleri \\
\hline \multicolumn{5}{|l|}{ Kuşak } \\
\hline $\mathrm{X}$ & 90 & 4.172 & 1.026 & \multirow{3}{*}{$\begin{array}{l}F=5.620 \\
p=0.004\end{array}$} \\
\hline $\bar{Y}$ & 168 & 4.115 & 1.099 & \\
\hline $\bar{Z}$ & 173 & 3.740 & 1.373 & \\
\hline \multicolumn{5}{|l|}{ Cinsiyet } \\
\hline Kadın & 243 & 4.118 & 1.190 & \multirow{2}{*}{$\begin{array}{l}\mathrm{t}=2.606 \\
\mathrm{p}=0.010\end{array}$} \\
\hline Erkek & 197 & 3.815 & 1.226 & \\
\hline \multicolumn{5}{|l|}{ Medeni Durum } \\
\hline Evli & 126 & 4.141 & 1.086 & \multirow{2}{*}{$\begin{array}{l}\mathrm{t}=1.906 \\
\mathrm{p}=0.058\end{array}$} \\
\hline Evli Değil & 315 & 3.912 & 1.261 & \\
\hline \multicolumn{5}{|l|}{ Eğitim Durumu } \\
\hline Temel Eğitim & 90 & 3.585 & 1.452 & \multirow{4}{*}{$\begin{array}{l}F=4.784 \\
p=0.003\end{array}$} \\
\hline Ön Lisans & 71 & 4.159 & 1.123 & \\
\hline Lisans & 235 & 4.103 & 1.120 & \\
\hline Lisansüstü & 43 & 3.837 & 1.193 & \\
\hline \multicolumn{5}{|l|}{ Aylık Gelir (TL) } \\
\hline-999 & 101 & 4.062 & 1.127 & \multirow{5}{*}{$\begin{array}{l}F=0.558 \\
P=0.693\end{array}$} \\
\hline $1000-1999$ & 71 & 4.150 & 1.120 & \\
\hline $2000-2999$ & 46 & 3.996 & 1.251 & \\
\hline $3000-3999$ & 38 & 4.236 & 1.084 & \\
\hline $4000+$ & 98 & 3.959 & 1.165 & \\
\hline \multicolumn{5}{|l|}{ Çalışma Durumu } \\
\hline Kamu Sektörü & 108 & 4.071 & 1.081 & \multirow{3}{*}{$\begin{array}{l}F=2.439 \\
p=0.088\end{array}$} \\
\hline Özel Sektör & 70 & 4.202 & 1.140 & \\
\hline Öğrenci & 262 & 3.876 & 1.281 & \\
\hline
\end{tabular}

MHRS bilgisi ve kullanılması boyutunun puanları katılımcıların cinsiyetine göre karşılaştırıldığında istatistiksel olarak anlamlı bir fark bulunmuştur $(t=2.606, p=0.010)$. Erkeklerin kadınlara göre puanlarının daha yüksek olduğu görülmüştür. Bu nedenle erkeklerin kadınlara göre MHRS bilgisi ve kullanımının daha fazla olduğu sonucu çıkmaktadır. MHRS bilgisi ve kullanılması boyutunun puanları katılımcıların ait olduğu kuşağa göre karşılaştırıldığında kuşaklar arasında istatistiksel olarak anlamlı bir fark olduğu bulunmuştur $(\mathrm{F}=5.620, \mathrm{p}=0.004)$. Yapılan Tukey's-b testi sonucunda farklılığın X kuşağının diğer kuşaklara göre en yüksek değeri almasından kaynaklandığı ortaya çıkmıştır. Buradan hareketle X kuşağının MHRS konusunda bilgi ve kullanım düzeylerinin yüksek söylenebilir. Bunun yanı sıra MHRS bilgisi ve kullanılması boyutunun puanları katılımcıların eğitim durumuna göre karşılaştırıldığında kuşaklar arasında istatistiksel olarak anlamlı bir fark olduğu bulunmuştur $(\mathrm{F}=4.784, \mathrm{p}=0.003)$. İleri analizlerde Tukey's-b testi sonucunda farklılığın ön lisans grubunun temel eğitim, lisans ve lisansüstü grubundan daha yüksek bir değer almasından kaynaklandığı ortaya çıkmıştır. 
e-Nabız ve Mobil Sağlık Uygulaması Bilgisi Boyutunun Demografik Değişkenlere Göre Karşılaştırılması

Tablo 9. e-Nabız ve Mobil Sağlık Uygulaması Bilgisi Boyutunun Demografik Değişkenlere Göre Karşılaş̧tırılması

\begin{tabular}{|c|c|c|c|c|}
\hline Değişkenler & $\mathbf{N}$ & $\bar{X}$ & SS & $\begin{array}{l}\text { Test } \\
\text { Deăerleri }\end{array}$ \\
\hline \multicolumn{5}{|l|}{ Kuşak } \\
\hline $\mathrm{X}$ & 90 & 3.103 & 1.247 & \multirow{3}{*}{$\begin{aligned} \mathrm{F} & =16.485 \\
\mathrm{p} & =0.000\end{aligned}$} \\
\hline $\bar{Y}$ & 168 & 3.153 & 1.217 & \\
\hline $\bar{Z}$ & 173 & 2.475 & 1.088 & \\
\hline \multicolumn{5}{|l|}{ Cinsiyet } \\
\hline Kadın & 243 & 2.798 & 1.191 & \multirow{2}{*}{$\begin{array}{l}\mathrm{t}=-1.333 \\
\mathrm{p}=0.183\end{array}$} \\
\hline Erkek & 197 & 2.956 & 1.266 & \\
\hline \multicolumn{5}{|l|}{ Medeni Durum } \\
\hline Evli & 126 & 3.169 & 1.288 & \multirow{2}{*}{$\begin{array}{l}\mathrm{t}=3.179 \\
\mathrm{p}=0.002\end{array}$} \\
\hline Evli Değil & 315 & 2.747 & 1.180 & \\
\hline \multicolumn{5}{|l|}{ Eğitim Durumu } \\
\hline Temel Eğitim & 90 & 2.459 & 1.206 & \multirow{4}{*}{$\begin{array}{l}\mathrm{F}=5.350 \\
\mathrm{p}=0.001\end{array}$} \\
\hline Ön Lisans & 71 & 2.840 & 1.177 & \\
\hline Lisans & 235 & 2.949 & 1.204 & \\
\hline Lisansüstü & 43 & 3.263 & 1.265 & \\
\hline \multicolumn{5}{|l|}{ Aylık Gelir (TL) } \\
\hline-999 & 101 & 2.670 & 1.118 & \multirow{5}{*}{$\begin{array}{l}\mathrm{F}=2.931 \\
\mathrm{P}=0.021\end{array}$} \\
\hline 1000-1999 & 71 & 3.152 & 1.241 & \\
\hline $2000-2999$ & 46 & 2.876 & 1.146 & \\
\hline $3000-3999$ & 38 & 2.986 & 1.343 & \\
\hline $4000+$ & 98 & 3.212 & 1.305 & \\
\hline \multicolumn{5}{|c|}{ Çalışma Durumu } \\
\hline Kamu Sektörü & 108 & 3.094 & 1.283 & \multirow{3}{*}{$\begin{array}{l}\mathrm{F}=6.543 \\
\mathrm{p}=0.002\end{array}$} \\
\hline Özel Sektör & 70 & 3.169 & 1.276 & \\
\hline Öğrenci & 262 & 2.701 & 1.157 & \\
\hline
\end{tabular}

e-Nabız ve mobil sağlık uygulamaları bilgisi boyutu katılımcıların ait olduğu kuşağa göre karşılaştırıldığında anlamlı farklılık olduğu görülmektedir $(F=16.485, p=0.000)$. Y kuşağının en yüksek değere sahip olduğu yapılan ileri analizlerde ortaya çıkmıştır. Bu durumda Y kuşağının mobil sağlık uygulamaları hakkındaki bilgisinin diğer kuşaklara göre yüksek olduğu söylenebilmektedir. e-Nabız ve mobil sağlık uygulaması bilgisi boyutu medeni duruma göre karşılaştırıldığında istatistiksel olarak anlamlı bir fark bulunmuştur $(F=16.485, p=0.000) . \mathrm{Bu}$ sonuç ile evli bireylerin e-Nabız ve mobil sağlık uygulamalarından elde ettikleri doyum düzeyinin daha yüksek olduğu söylenebilir.

e-Nabız ve mobil sağlı uygulamaları boyutu katılımcıların eğitim durumu ile karşılaştırıldığında istatistiksel olarak anlamlı bir fark bulunmuştur ( $F=5.350, p=0.001)$. Tukey's-b testi ile farkın temel eğitim düzeyinin, lisans ve lisansüstü düzeyden anlamlı bir şekilde ayrılmasından kaynaklandığı ortaya çıkmıştır. Buradan hareketle bireylerin eğitim düzeyi arttıkça mobil sağlık uygulamalarından elde ettikleri doyumun da artacağı söylenebilir. Diğer taraftan e-Nabız ve mobil sağlık uygulamaları boyutu katılımcıların aylık geliri ile karşılaştırıldığında istatistiksel olarak anlamlı bir fark bulunmuştur $(\mathrm{F}=2.931, \mathrm{P}=0.021)$. 
Yapılan Tukey's-b testi ile farkın 0-999 gelire sahip olanların düşük, 4000 ve üzeri gelire sahip olanların yüksek değer almasından kaynaklandığı tespit edilmiştir. Bu nedenle gelir düzeyi yüksek olan kişilerin e-Nabız ve mobil sağlık uygulamaları hakkında bilgisinin yüksek olduğu söylenebilir. Son olarak e-Nabız ve mobil sağlık uygulamaları bilgisi boyutundan katılımcıların çalışma durumu karşılaştırıldığında istatistiksel olarak anlamlı bir fark bulunmuştur $(\mathrm{F}=6.543$, $\mathrm{p}=0.002$ ). Tukey's-b testi ile farkın özel sektörde çalışan bireylerin yüksek, öğrencilerin düşük değer almasından kaynaklandığı tespit edilmiştir. Bu durumda e-Nabız ve mobil sağlık uygulamaları hakkında özel sektör çalışanlarının daha fazla bilgi sahibi olduğu söylenebilir.

\section{Hastaneye Duyulan Ihtiyacın Azalması Boyutunun Demografik Değişkenlere Göre Karşılaştırılması}

Hastaneye duyulan ihtiyacın azalması bilgisi boyutunun demografi değişkenlere göre dağılımı Tablo 10'da verilmiştir.

Tablo 10. Hastaneye Duyulan İhtiyacın Azalması Boyutunun Demografik Değişkenlere Göre Karşılaştırılması

\begin{tabular}{|c|c|c|c|c|}
\hline Değişkenler & $\mathbf{N}$ & $\bar{X}$ & SS & Test Değerleri \\
\hline \multicolumn{5}{|l|}{ Kuşak } \\
\hline $\mathrm{X}$ & 90 & 2.422 & 1.033 & \multirow{3}{*}{$\begin{array}{l}F=3.960 \\
p=0.020\end{array}$} \\
\hline $\bar{Y}$ & 168 & 2.744 & 1.247 & \\
\hline $\bar{Z}$ & 173 & 2.843 & 1.137 & \\
\hline \multicolumn{5}{|l|}{ Cinsiyet } \\
\hline Kadın & 243 & 2.631 & 0.073 & \multirow{2}{*}{$\begin{array}{l}\mathrm{t}=-1.893 \\
\mathrm{p}=0.059\end{array}$} \\
\hline Erkek & 197 & 2.843 & 0.084 & \\
\hline \multicolumn{5}{|l|}{ Medeni Durum } \\
\hline Evli & 126 & 2.518 & 1.120 & \multirow{2}{*}{$\begin{array}{l}\mathrm{t}=-2.375 \\
\mathrm{p}=0.018\end{array}$} \\
\hline Evli Değil & 315 & 2.803 & 1.183 & \\
\hline \multicolumn{5}{|l|}{ Eğitim Durumu } \\
\hline Temel Eğitim & 90 & 2.720 & 1.216 & \multirow{4}{*}{$\begin{array}{l}F=0.671 \\
p=0.570\end{array}$} \\
\hline Ön Lisans & 71 & 2.882 & 1.182 & \\
\hline Lisans & 235 & 2.702 & 1.172 & \\
\hline Lisansüstü & 43 & 2.581 & 1.074 & \\
\hline \multicolumn{5}{|l|}{ Aylık Gelir (TL) } \\
\hline-999 & 101 & 2.694 & 1.160 & \multirow{5}{*}{$\begin{array}{l}\mathrm{F}=1.039 \\
\mathrm{P}=0.387\end{array}$} \\
\hline $1000-1999$ & 71 & 2.873 & 1.148 & \\
\hline $2000-2999$ & 46 & 2.663 & 1.199 & \\
\hline $3000-3999$ & 38 & 2.447 & 1.118 & \\
\hline $4000+$ & 98 & 2.590 & 1.132 & \\
\hline \multicolumn{5}{|c|}{ Çalışma Durumu } \\
\hline Kamu Sektörü & 108 & 2.560 & 1.148 & \multirow{3}{*}{$\begin{array}{l}F=2.842 \\
p=0.059\end{array}$} \\
\hline Özel Sektör & 70 & 2.573 & 1.107 & \\
\hline Öğrenci & 262 & 2.835 & 1.86 & \\
\hline
\end{tabular}

Hastaneye duyulan ihtiyacın azalması boyutu kuşaklara göre karşılaştırıldığında istatistiksel olarak anlamlı bir fark bulunmuştur $(\mathrm{F}=3.960, \mathrm{p}=0.020)$. Tukey's-b testi ile yaş arttıkça hastaneye duyulan ihtiyaçta azalma olduğu ortaya çıkmıştır. X kuşağ en düşük değer alırken $\mathrm{Z}$ kuşağı en yüksek değeri almıştır. Bu nedenle $\mathrm{Z}$ kuşağı gelecekte hastanelere daha az ihtiyaç duyacak şeklinde yorum yapılabilir. Hastaneye duyulan ihtiyacın azalması boyutu medeni duruma göre karşılaştırıldığında istatistiksel olarak anlamlı bir fark bulunmuştur $(\mathrm{t}=-2.375, \mathrm{p}=$ 
0.018). Tukey's-b testi ile evli olmayan bireylerin daha yüksek değer alarak evli bireylerden ayrıldığ 1 tespit edilmiştir. Bu nedenle evli olmayan bireylerin hastaneye daha az ihtiyaç duyduğu sonucu çıkarılabilir.

\section{Tartışma ve Sonuç}

Sağlık ve teknolojinin iş birliğiyle sunulan sağlık hizmetleri tarihi eski yıllara dayanmaktadır. Dünyada hemen hemen her ülke sağlık kuruluşlarında bu teknolojileri aktif bir şekilde kullanmaktadır. Ancak sağlık teknolojileri bireysel olarak ele alınırsa tüketici sağlığı bilişiminin tarihi çok eski değildir. Özellikle son birkaç on yılda yaygınlaşmaya başlayan tüketici sağlığı bilişiminde bireylerin sağlıklarını kendilerinin yönetmesi hedeflenmektedir. Literatür incelendiğinde Türkiye'de bireyin kullanabildiği sağlık teknolojileri mevcutken kavrama yönelik bir çalışmaya rastlanmamıştır. Bu açıdan araştırmanın sonuçlarının değerli olduğu düşünülmektedir.

$\mathrm{Bu}$ çalışmada bireylerin sağlık hizmetlerinde tüketici sağlığı bilişimi kullanımlarına yönelik değerlendirme yapmaları istenmiştir. Çalışma kapsamında Isparta il merkezinde ikamet eden toplam 431 kişiye ulaşılmıştır. Araştırmacı tarafından oluşturulan anketin ifadeleri faktör analizi sonucunda 7 boyutta toplanmıştır.

Fayda algısı boyutu bakımından çalışmada katılımcıların tüketici sağlığı bilişimine yönelik fayda algıları “... sağlık teknolojisini faydalı buluyorum.” ifadeleri ile ölçülmüş ve bu teknolojileri faydalı buldukları (Tablo 4) ortaya çıkmıştır. Benzer bir sonuca Wilson ve Lankton'un (2004) yararlılık algısı boyutu ismiyle ve "e-Sağlık sağlik hizmetlerindeki sağglk bakımı yönetmedeki etkinliği arttıracak.", "e-Sağlık kullanmak sağlık hizmetlerinin kritik yönlerini destekleyecek." ve "e-Sağlık genel olarak sağlık hizmeti vermede yararl olacak." ifadeleriyle ölçtüğü çalışmada da rastlanmıştır.

Çalışmada katılımcıların sağlıkta ileri teknoloji kullanımı beklentisi ölçülürken "Gelecekte... olacağını dü̧̈ünüyorum.” ifadeleri kullanılmış ve sağlıkta ileri teknoloji kullanımı beklentisi boyutu olarak adlandırılmıştır. Çalışma sonucunda bireylerin sağlık teknolojilerinden beklentilerinin çok yüksek olduğu ortaya çıkmıştır (Tablo 5). Venkatesh ve arkadaşlarının (2003) çalışmasında benzer ifadeler "Gelecekte... kullanacağımı tahmin ediyorum.", "Gelecekte... kullanmayı planlıyorum." şeklinde olup kullanma niyeti boyutu olarak adlandırılmış ve beklenti düzeyinin benzer bir şekilde çok yüksek (4.97) olduğu sonucuna ulaşılmıştır. Aynı şekilde Polonya'da yapılan bir çalışmada beklenti düzeyinin düşük olduğu sağlık hizmetlerinde yer alan yapay zekâ teknolojilerinin geliştirilmesi ve yaygınlaştırılması gerektiği sonucu ulaşılmıştır (Ziuzianski vd. 2014).

Katılımcıların sağlıkta ileri teknoloji kullanımı beklentisi boyutunda "Gelecekte giyilebilir teknolojilerin daha sık kullanılacağını düşünüyorum." ifadesinde (3.24) çıkan sonuca benzer olarak Bower ve Sturman'ın (2015) çalışmasında da rastlanmıştır. Ek olarak çalışmada katılımcılar sağlıkta ileri teknoloji kullanımı beklentisi boyutu eğitim durumuna göre değerlendirildiğinde eğitim düzeyi yüksek olan kişilerin bilgi düzeylerinin yüksek (3.219) 
olduğu görülmüştür. Sunder ve Marathe'nin çalışmasında sağlıkta ileri teknolojik beklentilere sahip kişilerin eğitim düzeyi yüksek, vizyon sahibi uzman kişiler olduğuna yönelik benzer bir sonuca ulaşılmıştır (Sundar ve Marathe, 2010). Sağlıkta ileri teknoloji kullanımı beklentisi boyutu cinsiyete göre ele alındığında anlamlı bir farklılık ortaya çıkmış, erkeklerin (2.949) kadınlardan (2.445) daha fazla bilgi sahibi olduğu sonucu çıkarılmıştır. Çalışmadan farklı olarak Jackson ve arkadaşları (2008) ileri teknoloji beklentisini cinsiyet göre karşılaştırdığında kadınların (5.17 - 4.07) erkeklerden (4.69 - 2.52) daha bilgili olduğu sonucuna ulaşmıştır.

Sağlıkta teknoloji okuryazarlığı boyutu kuşaklara göre karşılaştırıldığında, X kuşağı bireylerinin okuryazarlık oranının en düşük, Y kuşağının ise en yüksek değere sahip olduğu tespit edilmiştir. Aynı şekilde Chou ve arkadaşlarının (2009) yaptığı bir çalışmada Y kuşağına dâhil olan orta yaş grubunun bilgi öğrenimi için sosyal medya araçlarını daha sık kullandığı sonucuna ulaşılmıştır. Çalışmada MHRS bilgisi ve kullanımı boyutundaki ifadelerin yüksek değerler alması katılımcıların MHRS'yi yaygın olarak kullandıklarını ifade etmektedir (Tablo 8). Benzer olarak Andreassen ve arkadaşlarının (2007) yaptığı çalışmada sağlık teknolojilerinde randevu uygulaması hakkında daha fazla bilgi sahibi olunduğu ve daha sık kullanıldı̆̆ı (internet kullanıcılarının \%71'i) sonucuna ulaşılmıştır.

Çalışmada katılımcıların e-Nabız ve mobil sağlık uygulaması bilgisi boyutu kuşaklara göre karşılaştırıldığında ise X ve Y kuşaklarının hemen hemen aynı düzeyde (3.103-3.153), Z kuşağın ise bilgisinin diğer kuşaklara göre düşük (2.475) olduğu tespit edilmiştir. Benzer bir sonuca Hesse ve arkadaşlarının (2005) çalışmasında da rastlanmıştır. Çalışmada 18-34 ya da 35-64 yaş aralığında olan bireylerin sağlık hizmetlerinde sağlık teknolojilerine yönelme oranları neredeyse birbirine eşit (\%38.9 - \%46.6) olurken 65 yaş üstü bireylerin ise oranı oldukça düşük ancak sağlık hizmeti sağlayıcılarına gitme oranı oldukça fazladır $(\% 75,6)$. Diğer taraftan farklı bir sonuca Andreassen ve arkadaşları (2007) e-Sağlıkla ilgili çalışmasında ulaşılmıştır. Çalışmada yaş arttıkça kullanım düzeyince azalma olduğu tespit edilmiştir.

Hastaneye duyulan ihtiyacın azalması boyutu katılımcıların yaşına göre değerlendirildiğinde yaş arttıkça gelecekte sağlık teknolojilerinden beklenti düzeyinin düştüğü ortaya çıkmıştır. Hesse ve arkadaşlarının (2005) çalışmasında benzer bir sonuca göre X kuşağının genellikle sağlık hizmeti alırken bir sağlık kuruluşuna başvurma oranı oldukça yüksektir (\%75.6). Genellikle bir sağlık kuruluşundan hizmet alan X kuşağı için bu durum onu teknolojiden daha da uzaklaştırmaktadır. Haliyle gelecekte de sağlık teknolojilerinden beklentisi düşük olmaktadır. Ancak teknoloji ile büyüyen Y kuşağı ve teknoloji çocukları olan Z kuşağının geleceğe yönelik beklentileri oldukça fazladır.

Çalışmaya katılan bireylerin yaş değişkenlerine göre karşılaştırılması yapıldığında fayda algısı, sağlıkta ileri teknoloji bilgisi, MHRS bilgisi ve kullanımı, e-Nabız ve mobil sağlık uygulaması bilgisi ve hastaneye duyulan ihtiyacın azalması boyutlarında anlamlı bir farklılık olduğu tespit edilmiştir. Y kuşağı (38-20) bireylerin yani orta yaşı kapsayan bireylerin sağlık teknolojileri konusunda fayda algısı ve bilgi düzeylerinin daha fazla olduğu saptanmıştır. Diğer taraftan 
geleceğe yönelik çalışmalar açısından Z kuşağı (19-18) genç bireylerin beklenti düzeyinin daha yüksek olduğu saptanmıştır. Bu durumda;

- X kuşağı bireylerinin hastaneye daha çok ihtiyaç duydukları ancak tüketici sağlı̆̆ bilişimi teknolojileri hakkında bilgilerinin az olduğu,

- Y kuşağı bireylerinin teknoloji ile büyüdükleri ve sağlık hizmetlerine ihtiyaç duydukları an hangi tüketici sağlığı bilişimi teknolojisine başvurması gerektiğinin bilincinde olduğu,

- Z kuşağının ise hayatlarının her anının teknoloji ile geçtiği ancak yaşları gereği sağlık hizmetlerine ihtiyaç duymamalarından dolayı bu teknolojiler hakkında bilgi ve kullanım düzeylerinin az olduğu değerlendirmesi yapılmaktadır.

Demografik değişkenlerden kuşak grubuna bakıldığında, kuşakların boyutlara göre kullanım düzeylerinin değişkenlik gösterdiği sonucuna ulaşılmıştır. Fayda algısı boyutunda en çok Y kuşağı bireylerinin sağlık teknolojilerin faydalı bulduğu, sağlıkta ileri teknoloji bilgisi boyutunda en çok Y kuşağının bilgili olduğu ve e-Nabız ve mobil sağlık uygulamaları bilgisi boyutunda en çok Y kuşağının bilgili olduğu sonucuna ulaşılmıştır. Diğer taraftan MHRS bilgisi ve kullanımı boyutunda en çok X kuşağının bilgi ve kullanımının yüksek olduğu ve hastaneye duyulan ihtiyacın azalması boyutunda gelecekte hastane ihtiyacının azalması düşüncesine en çok Z kuşağının katıldığ 1 sonucuna ulaşılmıştır. Buradan yola çıkarak X kuşağ bireylerinin birden çok boyutta geri planda yer almasının nedeni kuşağın teknolojik gelişmelere uzak olmasıdır. Ancak her ne kadar X kuşağı kullanım düzeyi diğer kuşakların gerisinde olsa da beklenenin üstünde bir sonuç vermiştir. Bunun nedeni ise yaşlı bir kesime sahip ve sürekli olarak sağlı hizmetlerine gereksinim duymasından dolayı teknolojik hizmetlere ayak uydurmak zorunda olmasıdır. Y kuşağında ise orta yaşa sahip bireyler sağlık hizmetlerine ihtiyaç duydukları an tüketici sağlığı bilişimlerine rahatlıkla başvurmaktadır. Bunun nedeni olarak bireylerin teknoloji ile beraber doğmaları ve bütün gelişmeleri yakından takip etmeleridir. Son olarak Z kuşağının tüketici sağlığı bilişimine uzak olduğu sonucuna varılmıştır. Her ne kadar teknolojiye hükmetmek Z kuşağı için basit olsa da genç bir nesil olan bu kuşağın henüz sağlık hizmetlerine ihtiyaç duymaması neden olarak gösterilmektedir. 


\section{Kaynakça}

Anderson, K.M., Marsh, C.A., Flemming, A.C., Isenstein, H. ve Reynolds, J. (2012). Quality Measurement Enabled by Health IT: Overview, Possibilities, and Challenges, United States, Agency for Health Research and Quality Advancing Excellence in Health Care Publication No. 12-0061-EF.

Andreassen, H.K., Bujnowska-Fedak, M.M., Chronaki, C.E., Dumitru, R.C., Pudule, I., Santana, S., Voss, H. ve Wynn, R. (2007). European Citizens Use of E-health Services: A Study of Seven Countries, BMC Public Health, 7(53):,1-7.

Biztatar, H. (2017). Olumsuz Elektronik Ağızdan Ağıza Pazarlama İletişimine Etki Eden Faktörler: Z Kuşă̆ı Tüketicilerinin Görüşlerini Belirlemeye Yönelik Bir Araştırma. (Yüksek Lisans Tezi), Çă̆ Üniversitesi Sosyal Bilimler Enstitüsü, Mersin.

Bower, M., Sturman, D. (2015). What are the Educational Affordances of Wearable Technologies?, Computer and Education, 88, 343-353.

Büyükkeçeci, E. (2017). Generation Z in Beginning Design Studio: A Case Study in Art and Design Studio at Izmir University of Economics. (Yüksek Lisans Tezi), İzmir Ekonomi Üniversitesi Sosyal Bilimler Enstitüsü, İzmir.

Büyükuslu, F. (2017). Z Kuşağııın İş Yaşamından Beklentileri Konusunda Bir Araştırma. (Yüksek Lisans Tezi), Bahçeşehir Üniversitesi Sosyal Bilimler Enstitüsü, İstanbul.

Cheong, H.J., Shin, N.Y. ve Joeng, Y.B. (2009). Improving Korean Service Delivery System in Health Care: Focusing on National E-health System, International Conference on eHealth, Telemedicine, and Social Medicine.

Chou, W.Y.S., Hunt, Y.M., Beckjord, E.B., Moser, R.P. ve Hesse, B.W. (2009). Social Media Use in the United States: Implications for Health Communication, Journal of Medical Internet Research, 11(4), 1-12.

Dişçi, R. (2008). Temel ve Klinik Biyoistatistik (1. Baskı). İstanbul: İstanbul Tıp Kitabevi.

Eysenbach, G. (2000). Recent Advances Consumer Health Informatics. British Medical Journal, 320(7251), 1713-1716.

Ferguson, T. (1993). Doctom's FAQ: What is Consumer Health Informatics?. Erişim Tarihi 11 Nisan 2019, https://www.fergusonreport.com/articles/tfr07-03.htm

Gibbons, M.C., Wilson, R.F., Samal, L., Lehmann, C.U., Dickersin, K., Lehmann, H.P., Aboumatar, H., Finkelstein, J., Shelton, E., Sharma, R. ve Bass, E.B. (2011). Consumer Health Informatics: Results of a Systematic Evidence Review and Evidence Based Recommendations. Translation Behavioral Medicine, 1(1), 72-82.

Hesse, B.W., Nelson, D.E. ve Kreps, G.L. (2005). Rust and Sources of Health Information the Impact of the Internet and Its Implications for Health Care Providers: Findings From the First Health Information National Trends Survey, Jama Internal Medicine, 165(22), 26182624. 
Jimison, H.B., Sher, P.P. (1995). Consumer Health Informatics: Health Information Technology for Consumers, Journal of the American Society for Information Science, 46(10), 783-790.

Keleş, A. (2007). Öğrenme- Öğretme Sürecinde Yapay Zekâ ve Web Tabanlı Zeki Öğretim Sistemi Tasarımı ve "Matematik Öğretiminde Bir Uygulama (Doktora Tezi), Atatürk Üniversitesi Fen Bilimleri Enstitüsü, Erzurum.

Kreps, G.L. ve Neuhauser, L. (2010). New Directions in Ehealth Communication: Opportunities and Challenges, Patient Education and Counseling, 78, 329-336.

Lerman, K. (2014). Healthcare Without Borders: How Millennials are Reshaping Health and Wellness. Boston.

Morgan, G.A., Leech, N.L., Gloeckner, G.W. ve Barrett, K.C. (2011). IBM SPSS for Introductory Statistics Use and Interpretation (40. Edition) New York: Taylor and Francis Group LLC.

Norman, C.D. ve Skinner, H.A. (2006) e-Health Literacy: Essential Skills for Consumer Health in a Networked World, Journal of Medical Internet Research, 8(2), 1-9.

Pagliari, C., Sloan, D. ve MacGillivray, S. (2005). What is e-health (4): A Scaping Exercise to Map the Field, Journal of Medical Internet Research, 7(1), e9.

Sağlık Bakanlığı (2014a). EHR (Electronic Health Record) - ESK (Elektronik Sağlık Kaydı). Erişim Tarihi 05 Ocak 2019, https://dijitalhastane.saglik.gov.tr/TR,4874/ehr-electronichealth-record---esk-elektronik-saglik-kaydi.html

Sağlık Bakanlığı (2016). Merkezi Hekim Randevu Sistemi. Erişim Tarihi 10 Ocak 2019, https://www.mhrs.gov.tr/Vatandas/hakkimizda.xhtml

Sundar, S.S. ve Marathe, S.S. (2010). Personalization versus Customization: The Importance of Agency, Privacy, and Power Usage, Human Communication Research, 36(3), 298-322.

Toygar, Ş.A. (2018). e-Sağlık Uygulamaları. Yasama Dergisi, 37, 101-123.

Venkatesh, V., Morris, M. G., Davis, G.B. and Davis, F.D., (2003). User Acceptance of Information Technology: Toward a Unified View, MIS Quarterly, 27(3), 425-478.

Wilson, E.V., Lankton, N.K. (2004). Modeling Patients Acceptance of Provider Delivered EHealth, Jamia a Scholary Journal of Informatics in Health and Biomedicine, 11(4), 241248.

World Health Organization (2009). Report of Information and Communication Technologies for Women's and Children's Health: a Planning Workbook, Geneva/Switzerland: World Health Organization.

World Health Organization (2011). Mhealth New Horizons for Health Through Mobile Technologies Global Observatory For Ehealth Series - Volume 3, Geneva/Switzerland, World Health Organization Global Observatory for eHealth.

World Health Organization (2016a). Global Diffusion of Ehealth: Making Universal Health Coverage Achievable Report of the Third Global Survey on Ehealth, Geneva/Switzerland: World Health Organization. 
World Health Organization (2019). What is a Health Technology?. Erişim Tarihi 11 Haziran 2019, https://www.who.int/health-technology assessment/about/healthtechnology/en/

Yazıcıoğlu, N. (2010). Yapay Zekâ ile Talep Tahmini. (Yüksek Lisans Tezi), Uludağ Üniversitesi Fen Bilimler Enstitüsü, Bursa.

Zach, S. (1996). Telemedicine Overview and Summary, Nineteenth Convention of the Institute of Electrical and Electronics Engineers (IEEE), Jerusalem, Israel, 409-412.

Ziuzianski, P., Furmankiwicz, M. and Soltysik-Piorunkiewicz, A. (2014). E-Health Artificial Intelligence System İmplementation: Case Study of Knowledge Management Dashboard of Epidemiological Data in Poland, International Journal of Biology and Biomedical Engineering, 8, 164-171. 